\title{
Muon collider gains momentum
}

\section{ミューオンコライダーをめざして}

Eric Hand

Nature Vol. 462(260-261)/19 November 2009

フェルミ研究所は、今後も物理学の最先端を走り続けるために、まだ実証されていない技術に望みを託光うとしている。

スイスのジュネーブ郊外にあるヨーロッパ 素粒子物理学研究所 (CERN) で、大型 ハドロン衝突型加速器 (LHC) の地下リン グを陽子ビームが再び駆け巡り始めたの は、つい最近のことである。ところが物理 学者たちは、早くもいくつかのチームに分 かれて LHC の後継加速器のデザインを競 い合っている。2009年 11 月の上旬には、 米国の科学者たちが大胆な計画を表明し た。世界初の「ミューオンコライダー」の 建造である。
コライダー (衝突型加速器) については、 以前から準備されている計画が 2 つる。 いずれも、長く、まっすぐなトンネルを通っ て加速された電子と陽電子を衝突させよ うとするリニアコライダーである。しかし、 米国イリノイ州バタヴィアのフェルミ国立 加速器研究所 (フェルミ研究所) の一部 の物理学者たちは、こうしたリニアコライ ダーの費用と実現可能性に不安を感じ、 LHC 以上に物理学の限界を押し広げるこ とができるかどうかも疑っている。彼らが

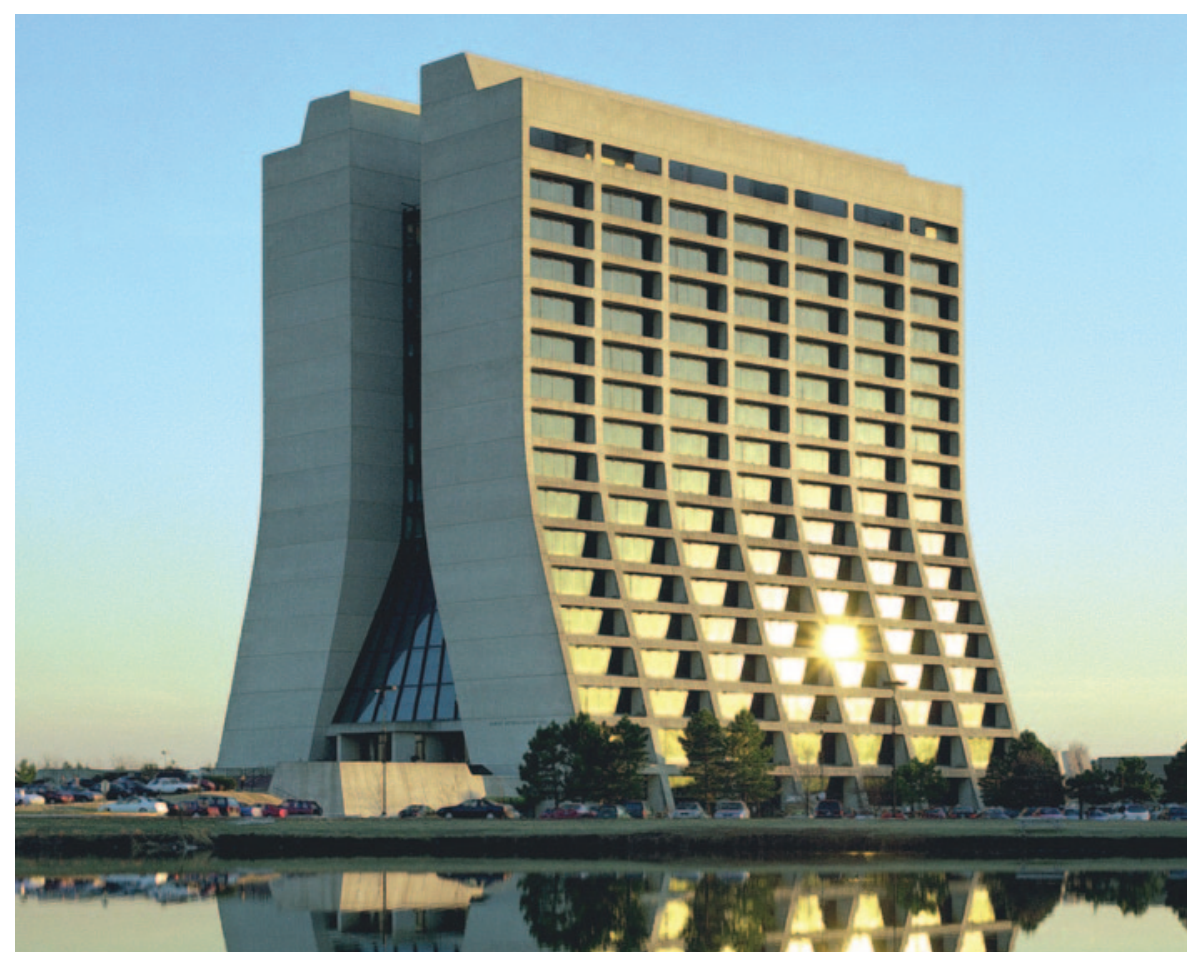

フェルミ研究所（上）は、これからも物理学の最先端を走り続けるために、ミューオンコライダーの建造 をめざしている。
その代わりに推しているのが、電子の約 200 倍の重さをもつミューオンを衝突させ るミューオンコライダーである。

フェルミ研究所は、2009 年 11 月 10 日から 12 日にかけてミューオンコラ イダーに関するワークショップを開催し た。フェルミ研究所の所長である Pier Oddone は、「問題は、それを建造でき るかどうかです」と語った。この会合は、 1990 年代の中ごろに最初に提案されてか ら長く冬眠状態にあったアプローチの復活 に向けて、重要な第一歩になるとみられて いる。これにより、ミューオンコライダーは、 先行する 2 つの加速器計画と直接競合す ることになる。その2つとは、米国、欧州、 アジアで分割して設計される全長 31 キロ メートルの「国際リニアコライダー (ILC)」、 そして既に LHC をもつ CERN が計画して いる全長 48 キロメートルの「コンパクト

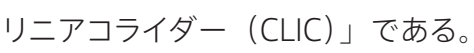

ミューオンコライダーの研究開発にはた いへんな困難が予想されるが、これが実 現すれば、電子コライダーよりも優れてい る点が多数あると考えられている。例えば、 ミューオンは電子に比べて重く、標的が広 くなるため、正面衝突しやすくなる。また、 ミューオンコライダーがヒッグス粒子（粒 子に質量を与える機構の 1 つと考えられ ているが、まだ観測されていない粒子) を生成する能力は非常に高いと期待され ており、ときに「ヒッグスファクトリー(ヒッ グス粒子工場)」とよばれることもある。 ただし、ミューオンの寿命は典型的には 


\section{大きさがすべてではない}

素粒子物理学の分野では、大型のコライダーほど高エネルギーでの衝突が可能になるが、その分、コストも高くなる傾向がある。しか し、ミューオンコライダーは、小さい設置面積と比較的低いコストで、高エネルギーでの衝突を可能にする。図中の 5 つの加速器のうち の 4 つについて主要な技術的構成要素の数の見積もりを行った、フェルミ研究所の物理学者 Vladimir Shiltsev によれば、ミューオ ンコライダーは、ほかの計画中の加速器に比べて単純な構造になるという。

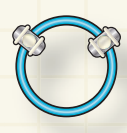

テバトロン 1985 年 現在 加速粒子：陽子 エネルギー：1 $1 \mathrm{TeV}$

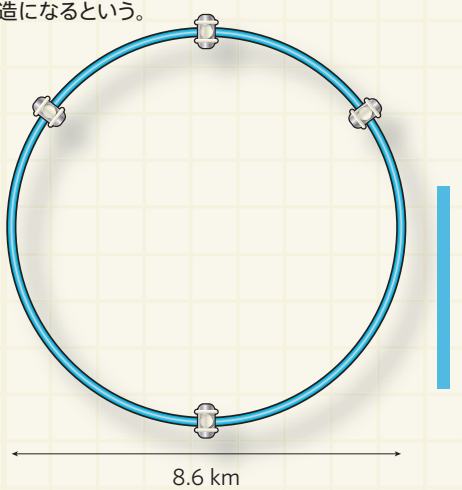

大型ハドロン衝突型加速器 (LHC)

最初のビーム衝突 : 2009 年

加速粒子：陽子

費用：46 億ドル

エネルギー：14TeV

構成要素の数 : 11,000

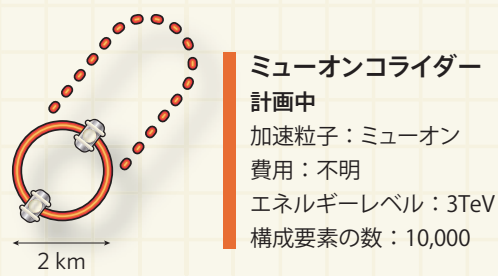

計画中

費用 : 不明

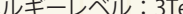

成要素の数 $: 10,000$

\section{コンパクトリニアコライダー(CLIC)}

\section{計画中}

加速粒子：電子

費用 : 2010 年中に見積もり

エネルギーレベル：3TeV

構成要素の数 : 260,000

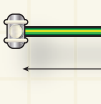

$\mathrm{H}=$

$48 \mathrm{~km}$

\section{2 マイクロ秒であるため、ミューオンを} 光速に近いスピードまで急激に加速し、— 般相対性理論の時間の伸びの効果を利用 して、寿命を引き伸ばす必要がある。

ミューオンは、磁場をかけて円形加速器 の中で加速してもエネルギーを失いにくい ため、比較的小さな（ゆえに安価な）リ ングで光速に近い速度まで加速することが できる。一方、電子を円形加速器で加速 する場合、これよりはるかに多くのエネル ギーがメ線の形で放射する（この光はシ ンクロトロン放射とよばれ、しばしば結晶 学に利用される)。

数百ギガ電子ボルト（1 ギガ電子ボルト は $10^{9}$ 電子ボルト) 以上のエネルギーを 達成する必要がある電子加速器では、電 子の運動をまっすぐに保つことでシンクロ トロン放射によるエネルギー損失を小さ くすることができる。けれどもそのために は、より大規模で、より高価なコライダー が必要となる (上に示した図参照)。円形 コライダーには、衝突率が高いという長 所もある。粒子が加速器の中を何周も回
るため、標的に衝突する機会が複数回与 えられるからである。これに対して、線形 コライダーの中の電子は、近づいてくる陽 電子と衝突する機会は 1 回しかないため、 ビームの位置を厳密に調節することが非 常に重要となる。

\section{ロビー運動}

Oddone は、つい数年前までILC（国際 リニアコライダー）のためのロビー運動 に奔走していたが（Nature 2005 年 6 月 9 日号 728 ページ参照)、今ではミューオ ンコライダーの推進派になっている。理由 の 1 つは、ミューオンコライダーが小さく、 フェルミ研究所のキャンパスにすっぽり入 るからである。フェルミ研究所には、現時 点で世界最高エネルギーの粒子加速器テ バトロンがあるが、LHC がその目標とす る 14 テラ電子ボルト（1 テラ電子ボルト は $10^{12}$ 電子ボルト) を達成すれば、トッ プの座から陷落する。一方で、フェルミ研 究所は、まもなく独自にミューオンを生成 できるようになる予定がある。あと 1 年か
2 年でテバトロンの運用が終了したら、「プ ロジェクトX」を開始することになってい るのだ。その強力な陽子ビームは、当初 はニュートリノの研究に用いることになる が、ミューオンの生成に利用することもで きる。Oddoneによれば、段階的にミュー オンコライダーの実現をめざすプログラム は、すべてを一気に完成させようとするプ ログラムよりも理にかなっているという。

フェルミ研究所は、国家レベルのミュー オン加速器プロジェクトを組織することと、 ミューオンコライダー研究のための補助金 を年間 900 万ドルから 1500 万ドルまで 増額することを米国エネルギ一省に要請し た。2009年 10 月 22 日にワシントン DC で開かれた高エネルギー物理学諮問会 議では、米国エネルギ一省科学局の局長 William Brinkman が、ILCが棚上げになっ た原因は、そのコストの高さにあったと指 摘した。彼は、フェルミ研究所がミューオ ンコライダーのアイディアを進めていくこ とを望んでいる。「真の革新が期待できる 方向をめざすのは、よいことです」。 
ミューオンコライダー推進派でも、ミュー オンコライダーの計画が ILC や CLIC の計 画に大きく遅れをとっており、これらに追 いつき、互角に渡り合えるようになるまで にはたいへんな努力をしなければならない ことを認めている。Oddone は、次世代 のコライダーが新しい物理学を生み出すた めに必要とされるエネルギーを LHC が明 らかにする 2012 年までに、より詳細なデ ザインコンセプトを固めたいと考えている。

一方、ILC 計画のリーダーであるカリフォ ルニアエ科大学（米国パサデナ）の名誉 教授 Barry Barish は、ミューオンコライ ダーの推進派は、その技術が実際にうま くいくことを証明する必要があると指摘す る。「フェルミ研究所の所長は、ミューオ ンコライダーの実現をめざしてロビー運動 を繰り広げていますが、だからといって、 米国以外の国々でその可能性がまじめに 受けとられているということにはなりませ ん」とBarish。

\section{泣きどころは費用}

ILC は、かつては次世代コライダーのデ ザインの中で明らかに優位に立っていた が、この 2 年間は苦戦を強いられてきた。 ILC は、急速に成熟してきた超伝導加速 技術を誇り、その実現に向けて積極的な スケジュールが立てられていた。しかし、 2007 年の末に米国と英国でILC 関係の 予算が削減された結果、その研究は事実 上終わりを告げた（Nature 2008 年 1 月 10 日号 112 ページ参照)。

米国カリフォルニア州のローレンス . バークレー国立研究所に所属してヨーロッ パの LHC 計画に取り組んでいる物理学者 の Robert Cahn は、ILCが抱えている最 大の問題は 200 億ドルの值札であると指 摘する。ILCが建造される可能性について、 彼はずばりといってのける。「ILC はもうお しまいですよ」。

Barish は、現在提案されているプロジェ クトの中でILC が最もよく練られているこ とに変わりはなく、実際のコストは、エネ
ルギー省が数十年前の価格を参照しては じき出した 200 億ドルという数字よりも、 2007 年に提出された 80 億ドルという見 積もりに近いだろうという。彼はまた、チー ムはデザインの変更を考えていて、これに よりコストを $15 \%$ 削減できると付け加えた。

とはいえ Barish も、LHC がこれから出 す結果次第では、ILCの建造をあきらめ ざるをえない事態になりうることは認めて いる。ILCの目標エネルギーは 500 ギガ 電子ボルトで、もっと高いエネルギー領域 を探る必要があることが明らかになった場 合、スケールアップは困難であるからだ。 より高いエネルギーを達成するためには、 ILC をもっと大きくする必要がある。その ためには、さらなる超伝導空洞とトンネル 掘りが必要であり、莫大な額の追加出費 が必要になるからだ。

ILCで問題となるエネルギーの限界を、 CLIC（コンパクトリニアコライダー）は巧 妙な方法で回避する。CLIC はILC のよう な超伝導空洞は使用せず、従来型の磁石 を、2 本のビームトンネルで使用する。第 一のトンネル內でビームを加速したら、技 師が急ブレーキをかけてエネルギーを吸 い上げ、第二のトンネル内の電子ビーム にそれを移すのだ。CERN で CLIC の研 究チームを率いる Jean-Pierre Delahaye は、今年中にデザインの検討を終える予 定なので、それまではプロジェクトの費用 を見積もることはできないという。けれど も、CLIC が目標とするエネルギーレベル はILCのピークエネルギーの 6 倍に相当 する 3 テラ電子ボルトであり、そのトンネ ルはILCより 20 キロメートル近く長くな る予定であるため、費用はILCよりはるか に高額になると見られている。また、CLIC は 440 メガワットという莫大な電力を必要 とする。これは、小型の原子力発電所 1 基分の出力に相当し、CERNに供給され ている電力を大幅に上回る。

3 つのデザインコンセプトの運命は、発 見のためにLHCがどのくらいのエネル ギーを必要とするかによって決まってくる。
多くの理論家は、超対称性（「量子の動 物園」にいる粒子の数を倍増させる理論) から新しい高エネルギー粒子が現れてくる と予想している。LHCがこれらを 1 つも 見つけられなかった場合、ILCの比較的 低いエネルギーではおもしろいものは大し て見つからない可能性が高まり、ミューオ ンコライダーを建造しようとするフェルミ 研究所が有利になる。

ミューオンコライダーの研究開発の先頭 に立つフェルミ研究所の Steve Geer は、 低エネルギーの超対称性粒子を除外する 実験から、間接的な証拠は既に得られて いるという。「いずれも、新しい物理学の ためのエネルギースケールがより高いとこ ろにあることを示唆しています」。

ミューオンコライダーで到達できるエネ ルギーは 3 テラ電子ボルトにすぎないが、 LHC では手の届かない領域の世界を探る ことができる。LHC が陽子を衝突させる工 ネルギーははるかに高いが、陽子はクォー クという小さい粒子からできているため、 衝突はずっと污く、電子またはミューオンを 衝突させるコライダーと比べると有効エネ ルギーが 1/10 になってしまうからである。

フェルミ研究所の MuCool (ミューオン イオン化冷却研究開発）実験のスポーク スマンである物理学者Alan Bross らは楽 観的だが、まずはミューオンコライダーに 関して最もやっかいな問題を解決しなけれ ばならない。MuCool 実験は、加速しよ うとするミューオンが崩壊してしまう前に、 高温のミューオンの雲を整列させ、低温 の細いビームとして進ませる方法を見いだ そうとしている。

Delahaye は、ライバルたちがミュー オンの研究を行うことを歓迎しているが、 ミューオンコライダーの有効性を実証でき るようになるまでには長い時間を要するか もしれないという。彼自身、実に1986 年 からCLICに取り組んできたのだ。「(ミュー オンコライダーのほうが）単純で安価であ るという結論に飛びつくのは軽率です」。 (三枝小夜子 訳) 